\title{
Evaluating the oestrogenic activities of aqueous root extract of Asparagus africanus Lam in female Sprague-Dawley rats and its phytochemical screening using Gas Chromatography- Mass Spectrometry (GC/MS)
}

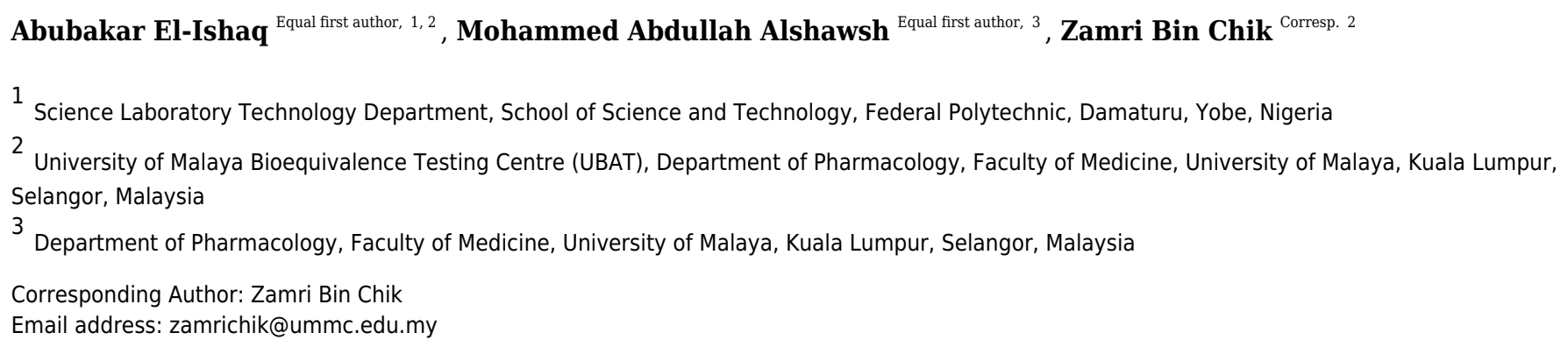

Asparagus africanus Lam. is a plant used traditionally for the treatment of natal cares. This study evaluates the oestrogenic activities of aqueous root extract and screens for possible bioactive phytochemicals. Oestrogenicity of $A$. africanus was evaluated in ovariectomised rats treated with 50,200 , and $800 \mathrm{mg} / \mathrm{kgBW}$ doses twice daily for three days. Ethinyl estradiol (EE)1 mg/kg was used as positive control, and hormonal analysis and gene expression were carried out. The findings demonstrated that the extract produced a dosedependent increase in the oestrogen levels with a significant increase compared to untreated rats. Pre-treatment with oestrogen receptor antagonist (ORA) prior to $A$. africanus treatment reversed the trend. Gene expression analysis on rats treated with $200 \mathrm{mg} / \mathrm{kgBW} A$. africanus showed significant $(p<0.005)$ upregulation of oestrogen receptor alpha $(E R \alpha)$, while pre-treating animals with (ORA) significantly $(p<0.005)$ increased the expression of calbindin 3 (Calb3) in the EE group as compared to the untreated rats. The GC/MS results showed the presence of steroidal saponins such as stigmasterol and sarsasapogenin. These might be the bioactive constituents that exhibited these activities. The oestrogenic properties of $A$. africanus revealed in this study could contribute to the antifertility properties of the plant. However, further pharmacological studies are required to confirm the antifertility effect. 


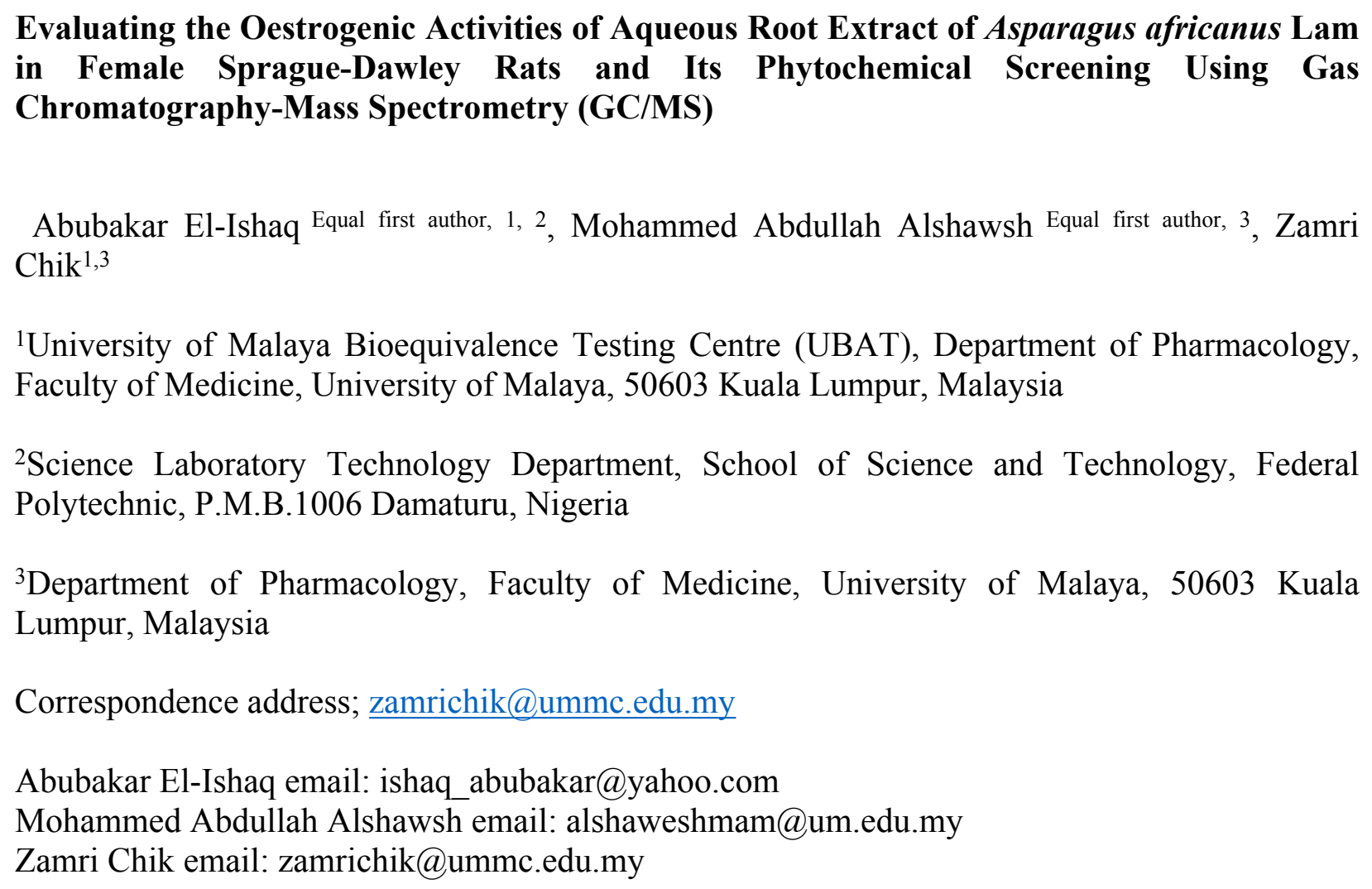

\begin{abstract}
Asparagus africanus Lam. is a plant used traditionally for the treatment of natal cares. This study evaluates the oestrogenic activities of aqueous root extract and screens for possible bioactive phytochemicals. Oestrogenicity of $A$. africanus was evaluated in ovariectomised rats treated with 50,200 , and $800 \mathrm{mg} / \mathrm{kgBW}$ doses twice daily for three days. Ethinyl estradiol (EE) $1 \mathrm{mg} / \mathrm{kg}$ was used as positive control, and hormonal analysis and gene expression were carried out. The findings demonstrated that the extract produced a dose-dependent increase in the oestrogen levels with a significant increase compared to untreated rats. Pre-treatment with oestrogen receptor antagonist (ORA) prior to $A$. africanus treatment reversed the trend. Gene expression analysis on rats treated with $200 \mathrm{mg} / \mathrm{kgBW} A$. africanus showed significant $(p<0.005)$ upregulation of oestrogen receptor alpha $(\mathrm{ER} \alpha)$, while pre-treating animals with ORA significantly $(p<0.005)$ increased the expression of calbindin 3 (Calb3) in the EE group as compared to the untreated rats. The GC/MS results showed the presence of steroidal saponins such as stigmasterol and sarsasapogenin. These might be the bioactive constituents that exhibited these activities. The oestrogenic properties of $A$. africanus revealed in this study could contribute to the antifertility properties of the plant. However, further pharmacological studies are required to confirm the antifertility effect.
\end{abstract}

Abbreviations: AEAA=Aqueous Extract of Asparagus africanus, $\mathrm{SD}=$ Sprague-Dawley, $\mathrm{ORA}=$ oestrogen receptor antagonist. 
47

48

49

50

51

52

53

54

\section{Introduction}

According to the World Health Organisation (WHO), approximately $80 \%$ of the world's population relies on traditional medicine which involves the use of plant extracts (WachtelGalor \& Benzie, 2011; WHO, 2011 ). This practice is more common among villagers where modern drugs are not available or are too expensive (Adamu et al., 2005). Asparagus africanus Lam, is a plant that is used in traditional medicine for contraception and to assist women during parturition. In addition, the aqueous extract of the plant is believed to have cleansing properties, especially after parturition and its roots contain polyphenols, phytosterol, saponins, and tannins (Yared, Mekonnen \& Debella, 2012). Other species of Asparagus (Asparagus pubescens) reportedly have the ability to reduce the number of pups output in rats, mice and rabbit species (Nwafor, Okwuasaba \& Onoruvwe, 1998). Medicinal plants have various actions on a body's physiology, and some plants contain phytoestrogen and may cause fertility, whereas others have abortifacient and antifertility activities (Mukta \& Nagendra, 2015).

Oestrogen is a vital hormone during development and maintenance of normal sexual and reproductive functions. Oestrogen is well known to be a morphogen and plays a vital role during morphogenesis of the uterus (Nina et al., 2007). Oestrogen signalling pathways are selectively promoted or inhibited depending on the balance between the activities of oestrogen receptors (ER $\alpha$ and $E R \beta)$ in target organs. Oestrogen receptors (ERs) belong to the steroidal hormone superfamily of nuclear receptors, which act as transcription factors after binding to oestrogen (Pillai, Jones \& Koos, 2002). In addition, oestrogen production is vital for proper implantation of 
71 the blastocyst with the uterine wall during pregnancy (Jeff et al., 2001). Oestrogens and

72 progestins are established modulators of the reproductive function in normal cycling and

73 remodelling during menses and pregnancy (Crabtree et al., 2006).

An uncontrolled population affects the socio-economic development of a country (Crabtree et al., 2006). To control population growth, there is a need for an acceptable female contraceptive (Londonkar \& Nayaka, 2013). Family planning has been promoted through several methods of synthetic contraceptives, but synthetic drugs have many adverse effects. Hence, there is a need to search for safe medicinal plants with contraceptive potentials free from adverse effects (Crabtree et al., 2006). However, due to the lack of intensive and comprehensive investigation, no safe and

81 effective oestrogenic plant has been found (Londonkar \& Nayaka, 2013).

A model used to evaluate the effect of chemicals on estrogen receptors is the uterotrophic assay in which removal of the ovaries reduces endogenous estrogens, causing the uterus to shrink. Replacement of these hormones with external sources of estrogen causes a trophic response of the uterus (Hye-Rim, Tae-Hee \& Kyung-Chul, 2012). The current study uses the uterotrophic assay to investigate the oestrogenic activities of aqueous extract of Asparagus africanus (AEAA) in female Sprague-Dawley rats to screen its phytochemical constituents using GC/MS.

Materials and Methods

\section{Chemicals and drugs}

Meloxicam was obtained from Bal Pharma, India. Fulvestrant (ICI 182, 870) and 17 $\alpha$-ethinyl estradiol were obtained from Sigma-Aldrich, Inc. St Louis. RNase plus mini, and RNase-Free

DNase kits were purchased from Qiagen, Germany. All chemicals are of analytical grade. 
Plant material collection and extraction

96

97

98

The sample of the A. Africanus plant was collected in Damaturu metropolitan, Yobe State, Nigeria. The plant was authenticated by plant Taxonomist (Dr. Kien-Thai, Yong) and the sampled plant was assigned a reference number (KLU 48696) and deposited in the Herbarium, University of Malaya. The root plant part was processed into a fine powder under laboratory conditions, and $50 \mathrm{~g}$ of fine powder was extracted in $500 \mathrm{~mL}$ of distilled water for $24 \mathrm{hr}$ (Dunn, Turnbull \& Sharon, 2004). The extract was filtered using Whatman filter paper No.4. and the filtrate was kept in the freezer at $-20^{\circ} \mathrm{C}$ before being evaporated to dryness in a vacuum using freeze dryer (Eyela FDU-1200, Japan) maintained at $-50^{\circ} \mathrm{C}$ for three days. The obtained yield of crude extract $(7.0 \%)$ was kept in a fridge at $4{ }^{\circ} \mathrm{C}$ for further analyses.

\section{Evaluation of the oestrogenic activity of Asparagus africanus}

All experimental procedures were carried out according to the approval of the ethics committee for animal experimentation, Faculty of Medicine, University of Malaya, Malaysia (Ethics Reference no.:2015-180505/PHAR/AEI). The female Sprague-Dawley rats were obtained from the animal experimentation unit, Faculty of Medicine, University of Malaya. The animals were housed in polycarbonate cages in a controlled environment (temperature, $23^{\circ} \mathrm{C} \pm 2{ }^{\circ} \mathrm{C}$; relative humidity, $50 \pm 10 \%$; frequent ventilation; and an illumination schedule of 12-h light/12-h dark). The experimental animals were allowed free access to phytoestrogen-free diet (Altromin 1324 FORTI) and tap water. Thirty immature bilaterally ovariectomised female Sprague-Dawley rats with body weights ranging from 160-180g were used for this study. The rats were randomly divided into five groups comprising six each $(n=6)$. Three groups of animals were administered a 
117 subcutaneous (SC) injection of Asparagus africanus extract dissolved in distilled water $\left(\mathrm{DH}_{2} \mathrm{O}\right)$

118 at three different doses $(50,200$ and $800 \mathrm{mg} / \mathrm{kgBW})$ twice daily for a total doses of 100,400 , and

$1191600 \mathrm{mg} / \mathrm{kg}$ per day for three consecutive days from day 14 to day 16 post ovariectomy (Bo-Mi

120 et al., 2009). Corn oil (5 ml/kg BW) and 17 -Ethinyl estradiol (EE: $1 \mathrm{mg} / \mathrm{kg} \mathrm{BW}$ ) were

121 administered SC and served as negative and positive control, respectively. The animals were

122 monitored for any clinical signs and abnormal behaviours daily throughout the experimental 123 period (Jain et al., 2016).

124

125 In the second batch of the experiment, another 30 rats $(n=6)$ were pre-treated with $\mathrm{SC}$ injection of $1 \mathrm{mg} / \mathrm{kg} \mathrm{BW}$ fulvestrant (ICI 182, 870), which is an oestrogen receptor antagonist (ORA), 30

127 minutes before each treatments. All animals were observed for vaginal cornification and early 128 vaginal opening (Marcondes, Bianchi \& Tanno, 2002; Srivastava et al., 2007) and were 129 euthanised $24 \mathrm{~h}$ after the last dose of treatment using an intraperitoneal overdose of $150 \mathrm{mg} / \mathrm{kg}$ 130 ketamine and $15 \mathrm{mg} / \mathrm{kg}$ xylazine. The body weights of the animals were recorded, and the uteri 131 tissues were harvested for gene expression analyses (Bo-Mi et al., 2009; Deepak, Rema \& Roy, 132 2015). The blood was collected, and the separated serum was used for hormonal analysis 133 (Yoshinaka et al., 2009).

Hormonal assay

ELISA kits (Thermo Fisher Scientific, USA) were used to measure oestrogen, progesterone and 137 luteinising hormone (LH) levels. Briefly, the plate was washed manually with $350 \mu 1$ washing 138 buffer and soaked for two minutes, followed by aspiration of the content from the plate. The 139 process was repeated three times. $50 \mu 1$ of standard or sample was added to each well and $50 \mu 1$ of 
140 antibody was added immediately to each well and incubated for $45 \mathrm{~min}$ at $37^{\circ} \mathrm{C}$. The plate was

141 washed three times and $100 \mu 1$ HRP-Streptavidin Conjugate (SABC) working solution was added

142 to each well and further incubated for 30 minutes at $37^{\circ} \mathrm{C}$. Aspiration was continued, and

143 washing procedures were repeated five times. Then, $90 \mu 1$ of tetramethylbenzidine (TMB)

144 substrate solution was added and the content incubated for $15-20$ minutes at $37^{\circ} \mathrm{C}$. Finally, $50 \mu 1$

145 of stop solution was added,and the absorbance was measured at $450 \mathrm{~nm}$ immediately. The result

146 was extrapolated from the plotted standard curve (FDA, 2016).

148 Gene expression assay

149 Quantitative reverse transcription polymerase chain reaction (RT-PCR) was carried out to 150 identify the expression levels of oestrogen receptor alpha (ER $\alpha)$ and calbindin-D9K (Calb3) 151 genes in treated and untreated rats. Total RNA was extracted from uterus tissues using RNase 152 plus mini kit (Qiagen, Germany), according to the manufacturer's protocol.

154 The concentration and purity of extracted RNA samples were determined by NanoDrop 155 spectrophotometer 2000c (Thermo Fisher Scientific, USA), while the quality of RNA was further 156 determined by Bioanalyzer Agilent RNA 6000 Nano Kit (Agilent, USA). One microgram of total 157 RNA was reverse transcribed to cDNA using high capacity RNA-to cDNA Master Mix supplied 158 by Applied Biosystems, USA. The obtained cDNA was stored at $-20^{\circ} \mathrm{C}$ until further used. For 159 RT-PCR, ER $\alpha($ Rn01640372_m1) and calbindin (Rn00560940_m1) assay genes were supplied 160 from TaqMan (Applied Biosystems, USA). A volume of $1 \mu 1$ complementary cDNA was used for 161 qPCR which was performed using standard conditions. The amplification and quantification 162 reactions were performed using the StepOne Plus Real-Time PCR System (Applied Biosystems, 
163 USA) according to TaqMan gene expression assay protocol. GAPDH (Rn0177563_g1) and

164 HPRT-1 (Rn01527840_m1) were used as the endogenous reference genes. Cycling kinetics was

165 performed in 40 cycles, to ensure linearity of PCR product (Thuy \& Eui-Bae, 2009). The real-

166 time PCR reaction was performed in triplicate, and the averages of the obtained threshold cycle

$167\left(C_{t}\right)$ values were processed for further calculations according to the comparative $C_{t}$ method.

168

169 Gene expression values were calculated according to the $2^{-\Delta \Delta \mathrm{Ct}}$ method (Livak \& Schmittgen,

170 2001). The $\Delta \mathrm{C}_{t}$ value of each sample was determined by subtracting the average $\mathrm{C}_{\mathrm{t}}$ value of the

171 endogenous reference genes from the average $C_{t}$ value of the target gene. The $\Delta \Delta C_{t}$ value was

172 then calculated by subtracting the $\Delta \mathrm{C}_{\mathrm{t}}$ value of the treated sample from the $\Delta \mathrm{C}_{\mathrm{t}}$ value of the

173 untreated control.

174 Finally, the gene expression levels were calculated as $2^{-\Delta \Delta \mathrm{Ct}}$ giving the final value that was

175 normalised to the reference genes and relative to the control sample values of the studied genes.

176 GenEx Enterprise software (MultiD Analyses, Sweden) for quantitative real-time PCR (qRT-

177 PCR) expression profiling, was used to analyse and normalise the qRT-PCR data (Kubista \&

178 Sindelka, 2007).

179

180 Phytochemical screening using GC/MS

$1815 \mathrm{mg}$ of aqueous root extracts was re-dissolved in $5 \mathrm{~mL}$ of deionised water and filtered using 182 polytetrafluoroethylene (PTFE) $0.2 \mu \mathrm{m}$ pore size. With the aid of a vial, $1.5 \mathrm{~mL}$ filtrate was 183 placed in the autosampler. Phytochemicals were screened using GC/MS -QP2010 ULTRA 184 (Shimadzu Corp., Japan) with electron impact ionisation. The column used was RTX (fused 
185 silica) column with the dimension of length $30.0 \mathrm{~m}_{\mathrm{x}}$ thickness $0.25 \mathrm{~mm}$, and diameter $0.25 \mu \mathrm{m}$

186 (Srivastava et al., 2015).

187 The GC/MS analysis was carried out under the following conditions; sample injection was 188 performed using a $10 \mu \mathrm{L}$ syringe with an injection volume of $1 \mu \mathrm{L}$. Helium gas was used as a 189 carrier gas with a flow rate of $4.8 \mathrm{~mL} / \mathrm{min}$ with a split ratio of 1:10. The temperature setting for 190 the column was $40^{\circ} \mathrm{C}$, which was later increased at 15 minutes of the start-up by $10{ }^{\circ} \mathrm{C}$ per 191 minute to $300{ }^{\circ} \mathrm{C}$. This temperature was maintained for 30 minutes. The total run time/post run 192 time was 48 minutes. The injector was set at room temperature, and detector voltage was 0.86 $193 \mathrm{kV}$. The mass spectrometer scan ranges were from 28-500 amu at 1 spectra/sec, with ionising 194 voltage and ionisation current of $70 \mathrm{eV}$ (Yuet et al., 2013; Srinivasa, et al., 2015).

Statistical analysis

197 The results were expressed as a mean \pm standard error of the mean (SEM). One way analysis of 198 variance (ANOVA) was employed for data comparison. GenEx statistical analysis was used for the gene expression, and analysis was performed using ANOVA followed by Tukey's post hoc test. A $p$-value $<0.05$ was considered indicative of a statistically significant difference.

\section{Results}

203

204

205

206

207

208

\section{Evaluation of the oestrogenic activity of Asparagus africanus}

The ethinyl estradiol (EE) treated group showed a significantly reduction in weight gain as compared to control for both with ORA $(p<0.005)$ and without ORA $(p<0.005)$. Figure 1 shows that the weight gains of groups treated with AEAA without ORA were 25.8, 40.5 and $57.6 \mathrm{~g}$ for the doses 50, 200 and $800 \mathrm{mg} / \mathrm{kg}$, respectively. The differences were not significant as compared

Peer) reviewing PDF | (2018:02:24158:2:0:NEW 3 Jun 2019) 
209 to control group (57.0 g). On the other hand, all AEAA treatment groups pre-treated with ORA

210 showed significant $(p<0.005)$ reduction in weight gain versus control (Figure 1$)$. The weight

211 gain reduction in the groups pre-treated with the ORA was in a dose-dependent manner, which

212 could be due to a positive synergy between AEAA and ORA.

213

214 The concentration of oestrogen (Figure 2) also depicted a dose-dependent increased pattern with

215 a significant increase in the treated animals without antagonist as compared to control. The mean

216 oestrogen levels of rats treated with AEAA in the absence of ORA were $94.0(p<0.05), 106.3$

$217(p<0.005)$ and $106.8(p<0.005) \mathrm{pmol} / \mathrm{L}$ for the doses 50, 200 and $800 \mathrm{mg} / \mathrm{kg}$, respectively,

218 which were significantly higher than control group (57.5 pmol/L). Administration of ORA prior

219 to the treatment reduced the levels of oestrogen as compared to the same group without the

220 antagonist. However, the level of oestrogen in all treated groups was significantly $(p<0.005)$

221 higher as compared to the control rats pre-treated with the antagonist.

222

223 The mean progesterone levels of rats treated with AEAA in the absence of ORA were 5.05, 5.53

224 and $3.68 \mathrm{nmol} / \mathrm{L}$ for the doses 50,200 and $800 \mathrm{mg} / \mathrm{kg}$, respectively, which were significantly $(p<$

$2250.005)$ lower than control group $(13.75 \mathrm{nmol} / \mathrm{L})$. However, with the administration of ORA, the

226 concentration of progesterone increased significantly $(p<0.005)$ in $800 \mathrm{mg} / \mathrm{kg}$ A. africanus

227 treated rats (Figure 3). Figure 4 shows the result of luteinising hormone (LH) for treated and 228 untreated SD rats and the results were statistically not significant between groups.

229

230

231

232 Figures 5 and 6 show the genes expression levels of rats treated without and with ORA, 233 respectively. Treated rats with $200 \mathrm{mg} / \mathrm{kgBW}$ A africanus showed significant $(p<0.005)$ 
234 upregulation of $\mathrm{ER} \alpha$ with 7.47 folds as compared to calibrator (Figure 5). While for the treated

235 animals with ORA, the Calb3 of ethynyl estradiol-treated group was significantly $(p<0.005)$

236 overexpressed with 7.64 folds as compared to the calibrator (Figure 6).

237

238

239

$240 \mathrm{GC} / \mathrm{MS}$ chromatogram of the aqueous root extract of $A$. africanus (Figure 7) shows nine

241 identifiable peaks indicating the presence of nine phytochemical compounds. Chromatograms and

242 spectrums obtained were identified using National Institute of Standards and Technology Library (NIST).

243 Mass Spectrum Search Interpreter version 11 database was used for possible chemical identification by

244 comparing the spectrum and the mass to charge ratio $(\mathrm{m} / \mathrm{z})$ of the identified peaks. The details of the

245 compounds are presented in Table 1. The findings revealed two phytoconstituents with steroidal

246 nucleus namely stigmasterol and sarsasapogenin that are structurally related to hormone

247 backbones. Furthermore, other non-steroidal compounds such as; 2(3H)-furanose, dihydro-3-

248 hydroxy-4,4-dimethyl; pyrazinetetramethyl; 1,2-benzenedicarboxylic acid; 7,9-Die-tertt-butyl-1-

249 oxospiro $(4,5)$ deca-6,9-diene-2,8-dione; n-Hexadecanoic acid; butyl citrate; and 3-Dehydro-des-

250 N-26-methyl-dihydro-pseudotomatidine were also detected. The mass spectrum of the identified

251 phytochemicals of aqueous root extract of $A$. africanusare attached as supplementary materials

252 and labelled as Figures S1 - S9.

253 


\section{Discussion}

255 The oestrogenic activity of plants which blocks foetal angiogenesis was suggested to probably 256 work through exerting anti-implantation (Jeff et al., 2001; Mukesh et al., 2006). Jeff and 257 colleagues reported that oestrogen secretion is very important for proper implantation of the 258 blastocyst with the uterine wall during early pregnancy (Jeff et al., 2001). In our study, the 259 AEAA demonstrated an increase in the level of oestrogen and a severe reduction in the 260 progesterone in a dose-dependent manner. This activity is anti-progestin in action, and 261 progesterone is required in preparation of the uteri for proper implantation of the blastocyst to 262 the uterine wall through the angiogenesis process. This could be a possible mechanism through which AEAA exerts its anti-implantation activity.

264 Our study revealed that AEAA has antiprogestins, and in the absence of progesterone, pregnancy cannot be initiated or maintained. The main function of the corpus luteum is secretion of progesterone hormone, which is important during the luteal phase of the menstrual cycle and for

267 maintenance of normal pregnancy in mammals (Donald, 1999). We observed that concentrations 268 of progesterone remained significantly low for all the treated groups $(p<0.005)$ when compared 269 with the control group. Moreover, with the pre-administration of ORA, the level of progesterone 270 increased significantly $(p<0.005)$ in $800 \mathrm{mg} / \mathrm{kgBW}$ of AEAA treated group. Furthermore,

271 luteinising hormone levels in AEAA treated and untreated SD rats showed non-significant 272 changes.

273 There are multiple mechanisms through which phytoestrogens exert its effect, including 274 alterations of oestrogen receptor expression (Andreana \& Edward, 2003). In our study, the $275 \mathrm{AEAA}$ at $200 \mathrm{mg} / \mathrm{kgBW}$ has significantly upregulated the expression of ER $\alpha$ in the rats without 276 ORA and down-regulated in the presence of the antagonist. Previous studies reported that AEAA 
277 might be a selective oestrogen receptor modulator (Ermias et al., 2014). In our study, the result

278 showed a selective pattern in terms of activities of AEAA on oestrogen receptors, which is an

279 example of selective estrogen receptor modulator (SERM) and an ideal SERM would have

280 antagonist activity on the uterus while having an agonist activity on other target tissues that

281 profit from an oestrogen-like action (Ilaria et al., 2014).

282

283

Expression of Calb3 in the uterine of endometrium increased during the pregnancy and the estrus cycle (Yohan et al., 2012). Likewise, there were changes during gestation of calb3 in the uterus and placenta (Catherine et al., 1989). AEAA at a concentration of $200 \mathrm{mg} / \mathrm{kgBW}$ has down-regulated the expression of calb3 gene in the absence of the ORA, however this reduction was not statistically significant. On the other hand, Calb3 expression was upregulated after administration the ORA, but again the overexpression was not statistically significant. Oestrogen has been known to increase the expression of Calb3 during early pregnancy (Yohan et al., 2012). Our finding also showed that EE significantly increased the expression of Calb3 in rats without ORA, which is in line with the reported data by Yohan et al., who showed that the expression of Calb3 in the uterine endometrium was under the regulation of oestrogen during pregnancy (Yohan et al., 2012). The increment in the level of estradiol concentration was usually connected to the increase in the level of Calb3 (Hong \& Jeung, 2013). The relationship between the dose of a bioactive compound and the pharmacological response (dose-response curve) is not always appears as a linear curve. In our study the level of progesterone and gene expressions of $\mathrm{ER} \alpha$ and Calb3 showed a non-monotonic dose-response curve, which is inconsistent with the typical curve of dose-response relationship. Such a dose response curve has been also reported with some endocrine disrupting compounds such as 
300 bisphenol A (Vandenberg, 2014). One of the proposed mechanisms resulting in such kind of 301 curve is the disruption in hormonal regulation (Vandenberg et al., 2012; Lagarde et al., 2015;

302 Vandenberg, 2014). This kind of non-linear dose-response curve could be explained by the low303 dose effects (Do et al., 2012; Vandenberg, 2014; Lagarde et al., 2015). Hence, we postulate that 304 some of the findings of our study suggest that the disruption on the hormonal regulation could 305 have been compensated by negative feedback response.

306 Many phytochemicals isolated from plants are capable of initiating and modulating hormonal 307 activities. A chemical isolated from the female part of Humulus lupulus "hops" is an example of 308 endocrine disruptor found in medicinal plant. The inflorescences parts of Humulus lupulus contains xanthohumol, which is converted by large intestine normal flora into 8-

310 prenylnaringenin. The phytoestrogen 8-prenaylnaringenin is a bioactive compound of hops and 311 one of the most potent phytoestrogens isolated until now has binding affinity to estrogen 312 receptors and may effect on menstrual cycles and decreases the fertility rate (Milligan et al., 313 2002).

314 The investigation of Asparagus africanus root extract shows the presence of polyphenols, 315 phytosterol, saponins and tannins (Yared, Mekonnen \& Debella, 2012). These phytochemicals 316 have been implicated to have oestrogenic properties in some animal species (Nwafor, 317 Okwuasaba \& Onoruvwe, 1998). Findings from GC/MS analysis revealed the presence of 318 phytoconstituents with a steroidal nucleus, namely stigmasterol and sarsasapogenin, which are 319 structurally related to hormones backbone. This result supports the findings by Geremew who 320 reported that plants might possess hormonal properties capable of modulating the reproductive 321 function of the experimental rats (Geremew, Yalemtsehay \& Eyasu, 2006). The presence of 322 steroidal saponins has also been reported by Asfaw et al., which is in agreement with our study 
323 (Asfaw et al., 1999). The findings of this study confirm that A. africanus contains potential

324 steroidal like compounds, which could explain the traditional uses of its root as pre-natal

325 alternative medicine or contraceptive.

326

327 Conclusion

328 The female rats treated with the root extract of $A$. africanus showed a significant increase in the 329 production of oestrogen and reduced levels of progesterone, which may indicate that A. africanus 330 root extract, could exert an abortifacient effect mainly by the oestrogenic and antiprogestin 331 effects. The GC/MS analysis of the root extract of $A$. africanus showed the presence of steroidal 332 saponins; stigmasterol and sarsasapogenin. These phytochemicals could explain the traditional 333 medicinal uses of $A$. africanus, especially in birth-related applications. Further pharmacological 334 studies should be carried out to investigate the efficacy of the plant, especially the antifertility 335 activities of the steroidal saponins identified in this plant.

336 Declarations

\section{Authors' contributions}

338 AE conceived the study, performed the experiment, monitored the animals, and assisted in manuscript preparation. ZC designed and coordinated the study. MAA interpreted the data and 340 coordinated the study. All authors read and approved the final manuscript.

\section{Acknowledgements}

342 The authors wish to express their gratitude to University of Malaya for their support for this 343 project and the Federal Polytechnic, Damaturu (Tetfund) for the postgraduate study scholarship.

\section{References}


Adamu, H. M., Abayeh, O., Agho, M., Abdullahi, A., Uba, A., Dukku, H., \& Wufem, B. 2005. An ethnobotanical survey of Bauchi State herbal plants and their antimicrobial activity. Journal of Ethnopharmacology, 99(1), 1-4.doi:10.1016/j.jep.2004.12.2025.

Andreana, L. O., \& Edward, J. K. 2003. Phytoestrogens: a Review of the Present State of Research. Phytotherapy ResearchPhytother. Res., 17, 845-869. doi:www.interscience.wiley.com). DOI: 10.1002/

Asfaw, D., Erst, H., Olaf, K., Gunter, M., \& Dawit, A. 1999. Steroidal saponins from Asparagus africanus. . Phytochemistry, 51, 1069-1075. doi.org/10.1016/S0031-9422(99)00051-5

Bajaj, V. K., \& Gupta, R. S. 2012. Fertility suppression in male albino rats by administration of methanolic extract of Opuntia dillenii. Andrologia, 44(SUPPL.1), 530-537. doi:10.1111/j.14390272.2011.01220.x

Bo-Mi, L., Geun-Shik, L., Eui-Man, J., Kyung-Chul, C., \& Eui-Bae, J. 2009. Uterine and placental expression of TRPV6 gene is regulated viaprogesterone receptor- or estrogen receptor-mediated pathwaysduring pregnancy in rodents. Reproductive Biology and Endocrinology 2009 7:49.doi:.org/10.1186/1477827-7049.

Catherine, L. M., Susan, H. B., Stacey, G. O., James, G. B., David, E. B., \& Elizabeth, B. M. 1989. transport and uterine muscle functionGestational changes in calbindin-D9k in rat uterus, yolk sac, and placenta: Implications for maternal-feta. Proc. Nati. Acad. Sci. USAPhysiological Sciences, 86, 3433-3437.

Crabtree, J. S., Zhang, X., Peano, B. J., Zhang, Z., Winneker, R. C., \& Harris, H. A. 2006. Development of a mouse model of mammary gland versus uterus tissue selectivity using estrogen-and progesterone-regulated gene markers. The Journal of steroid biochemistry and molecular biology, 101(1), 11-21. dio.org/10.1016/j.jsbmb.2006.06.017

Deepak , K. K., Rema, R., \& Roy, M. D. 2015. Additive effects of zoledronic acid and propranololon bone density and biochemical markers of boneturnover in osteopenic ovariectomized rats. $\mathrm{r}$ e v b r a s r e u m a t o 1. 55(2), 103-112. doi:Doi.org/10.1016/j.rbre.2014.09.008

Do R.P., Stahlhut R.W., Ponzi D., Vom Saal F.S., \& Taylor JA. 2012. Non-monotonic dose effects of in utero exposure to di (2-ethylhexyl) phthalate (DEHP) on testicular and serum testosterone and anogenital distance in male mouse fetuses. Reproductive toxicology 34:614-621.

Donald, R. M. 1999. Biologic Markers in Reproductive Toxicology. University of Arkansas for Medical Sciences: NATIONAL ACADEMY PRESS 2101 Constitution Avenue, NW Washington, DC 20418.

Dunn, J. L., Turnbull, J. D. a., \& Sharon, A. R. 2004. Comparison of solvent regimes for the extraction ofphotosynthetic pigments from leaves of higherplants. University of Wollongong.

Ermias, L., Zemede, A., Ensermu, K., \& Patrick, V. D. 2014. Ethnoveterinary plants of Ankober District, North Shewa Zone, Amhara Region, Ethiopia. Journal Of Ethnobiology and Ethnomedicine, 10(21), 2-19. doi:10.1186/1746-4269-10-21

FDA. 2016. Gold Standard M- Food and Drug Administration Retrieved from ttp//www.accessdata. fda.gov/cdrh_docs/pdf 13/ K131330.pdf. date retrieved 12th November 2016. Retrieved date retrieved 12th November 2016. doi:www.cfsan.fda.gov/ 1rd/fr990121.

Geremew, T., Yalemtsehay, M., \& Eyasu, M. 2006. Antifertility effect of aqueous and ethanol extracts of the leaves and roots of Asparagus africanus in rats. African Health Sciences; 6(2), 81-85.

Hong, E.-J., \& Jeung, E.-B. 2013. Biological Significance of Calbindin-D9k within Duodenal Epithelium. Int. J. Mol. Sci., 2013( 14), 23330-23340. doi:10.3390/ijms141223330

Hye-Rim, L., Tae-Hee, K., \& Kyung-Chul, C. 2012. Functions and physiological roles of two types of estrogen receptors, ER $\alpha$ and ER $\beta$, identified by estrogen receptor knockout mous. Lab Anim Res, 28, 71-76. doi:http://dx.doi.org/10.5625/lar.2012.28.2.71 
393

394

395

396

397

398

399

400

401

402

403

404

405

406

407

408

409

410

411

412

413

414

415

416

417

418

419

420

421

422

423

424

425

426

427

428

429

430

431

432

433

434

435

436

437

438

439

440

Ilaria, P., Carlotta, G., John, A. K., \& Filippo, M. 2014. Estrogen Receptors Alpha (ER $\alpha$ ) and Beta (ER $\beta)$ : Subtype-Selective Ligands and Clinical Potential. 15; 0: 13-29. . doi:10.1016/j.steroids.2014.06.012.

Jain, N. K., Jain, S., Mehta, S. C., \& Tonpay, S. D. 2016. Antiimplantation and Antiestrogenic Activity of $<\mathrm{i}>$ Boerhaavia Diffusa $</ \mathrm{i}>$ Root Extract in Female Albino Rats. American Journal of Pharmacological Sciences, 4(2), 15-19.

Jeff, R., Sanjoy, K. D., Bibhash, C. P., Hyunjung, L., Haengseok, S., Hiromichi, M., Sudhansu, K. D. 2001. Global Gene Expression Analysis to Identify Molecular Markers of Uterine Receptivity and Embryo Implantation. Journal of Biology and Chemistry, 276(47), Pages44137-44145. DOI:10.12691/ajps-4-2-1.

Kubista, M., \& Sindelka, R. 2007. The Prime Technique Real-time PCR Data Analysis. G.I.T. Laboratory Journal Europe. 11 no.9/10/2007, pp 33-35, GIT VERLAG GmbH \& Co. KG, Darmstadt, .

Lagarde F., Beausoleil C., Belcher S.M., Belzunces L.P., Emond C., Guerbet M., \& Rousselle C. 2015. Non-monotonic dose-response relationships and endocrine disruptors: a qualitative method of assessment. Environmental Health 14:13.

Livak, K. J., \& Schmittgen, T. D. 2001. Analysis of Relative Gene Expression Data Using Real-Time Quantitative PCR and the 2nd OCT Method. METHODS, 25, 402-408. doi:doi:10.1006/meth.2001.1262, available online at http://www.idealibrary.com

Londonkar, R. L., \& Nayaka, H. B. 2013. Effect of ethanol extract of Portulaca oleracea L on ovulation and estrous cycle in female albino rats. Journal of Pharmacy Research, 6(4), 431-436. doi:10.1016/j.jopr.2013.02.030

Marcondes, F. K., Bianchi, F. J., \& Tanno, A. P. 2002. Determination of the estrous cycle phases of rats: Some helpful considirations. Braz. J. Biol.,, 62(4A), 609-614. doi.org/10.1590/S1519-69842002000400008

Milligan, S., Kalita, J., Pocock, V., Heyerick, A., De Cooman, L., Rong, H., \& De Keukeleire, D. 2002. Oestrogenic activity of the hop phyto-oestrogen, 8-prenylnaringenin. Reproduction, 123, 235-242.

Mukesh, J., Aashima, N., Akhilesh, K. T., \& Jitendra, P. K. 2006. Validation of housekeeping genes as internal control for studying gene expression in rice by quantitative real-time PCR. Biochemical And Biophysical Research Communications, 345, , 646-651.

Mukta, V. A., \& Nagendra, P. 2015. A Critical Review on the Medicinal Plants Acting on Female Reproductive System. Atreya Ayurveda Publications, 3(6). doi:www.jahm.in

Nina, H., Ashley, P., Sandra, A., Jason, M., Guojun, C., Johan, H., . . Jan-A Ke, G. 2007. Estrogen Receptors: How Do They Signal and What Are Their Targets. Physiol Rev:,, 87, 905-931. doi:doi:10.1152/physrev.00026.2006.

Nwafor, P. A., Okwuasaba, F. K., \& Onoruvwe, O. O. 1998. Contraceptive and non-estrogenic effects of methanolic extract of Asparagus pubescens root in experimental animals. Journal of Ethnopharmacology, 62(2), 117-122. doi:http://dx.doi.org/10.1016/S0378-8741(98)00021-X

Pillai, S. B., Jones, J. M., \& Koos, R. D. 2002. Treatment of rats with $17 \beta$-estradiol or relaxin rapidly inhibits uterine estrogen receptor $\beta 1$ and $\beta 2$ messenger ribonucleic acid levels. Biology of Reproduction, 67(6), 1919-1926. doi.org./10.1095/bioreprod.102.003392.

Srinivasa, R. C., Ammani, K., \& Rose, M. T. 2015. GC-MS Studies of Maba buxifolia [Rottb.] Juss. Stem. Journal of Global Biosciences, 4(1), 1193-1197.

Srivastava, R., Mukerjee, A., \& Verma, A. 2015. GC-MS Analysis of Phytocomponents in, Pet Ether Fraction of Wrightia tinctoria Seed. Pharmacognosy Journal, 7(4), 249-253. doi:10.5530/pj.2015.4.7

Srivastava, S. R., Keshri, G., Bhargavan, B., Singh, C., \& Singh, M. M. 2007. Pregnancy interceptive activity of the roots of Calotropis gigantea Linn. in rats. Contraception, 75(4), 318-322. 
441

442

443

444

445

446

447

448

449

450

451

452

453

454

455

456

457

458

459

460

461

462

463

464

465

466

467

468

469

470

471

472

473
Thuy, T. B. V., \& Eui-Bae, J. 2009. An Evaluation of Estrogenic Activity of Parabens Using Uterine Calbindin-D9k Gene in an Immature Rat Mode. TOXICOLOGICAL SCIENCES, 112(1), 68-77. doi:https://doi.org/10.1093/toxsci/kfp176

Vandenberg L.N. 2014. Non-monotonic dose responses in studies of endocrine disrupting chemicals: bisphenol a as a case study. Dose-response 12:dose-response. 13-020. Vandenberg

Vandenberg L.N., Colborn T., Hayes T.B., Heindel J.J., Jacobs Jr D.R., Lee D-H, Shioda T., Soto A.M., vom Saal F.S., \& Welshons W.V. 2012. Hormones and endocrine-disrupting chemicals: low-dose effects and nonmonotonic dose responses. Endocrine reviews 33:378-455.

Wachtel-Galor, S., \& Benzie, I.F.F. 2011. Herbal Medicine: An Introduction to Its History, Usage, Regulation, Current Trends, and Research Needs. In: Benzie IFF, Wachtel-Galor S, editors. Herbal Medicine: Biomolecular and Clinical Aspects. (2nd edition. ed.). Boca Raton (FL):: CRC Press/Taylor \& Francis. Chapter 1.

WHO. 2011. World Health Organization . Traditional medicine factsheet. http://www.who.int/ mediacentre/factsheets/2003/fs134/en/

Yared, D., Mekonnen, Y., \& Debella, A. 2012. In vivo antimalarial activities of fractionated extracts of Asparagus africanus in mice infected with Plasmodium berghei. Pharmacologyonline, 3, 88-94. ISSN: 1827-8620. Retrieved from http://www.scopus.com/inward/record. url? eid =2-s2.084872843209\&partnerID=40\&md5 =dce1dd9f854b71473ef9 2557 5c 0d cc1 a.

Yohan, C., Heewon, S., Jangsoo, S., Mingoo, K., \& Hakhyun, K. 2012. Regulation of S100G Expression in the Uterine Endometrium duringEarly Pregnancy in Pigs. Asian-Australas J Anim Sci., 25((1)), 44-51. doi:10.5713/ajas.2011.11305.

Yoshinaka, U., Xi Jun, H., Tomonori, E., Yuichi, K., Junichi, K., \& Masahiro, M. M., Ikeya. 2009. Changes in Blood Parameters and Coagulation-Related Gene Expression in Pregnant Rats. Journal of the American Association for Laboratory Animal Science, 48(3), 272-278.

Yuet, P. K., Darah, I., Chen, Y., Sreeramanan, S., \& Sasidharan, S. 2013. Acute and subchronic toxicity study of Euphorbia hirta L. methanol extract in rats. Biomed Res Int, 2013, 182064. doi:10.1155/2013/182064 


\section{Figure 1}

Weight gain of rats treated with and without oestrogen receptor antagonist.

Values are expressed as mean $\pm \mathrm{SEM},(n=6),{ }^{* *} \mathrm{P}<0.005$ vs. control without antagonist, ${ }^{\# \#} \mathrm{P}<$ 0.005 vs. control with antagonist. $\mathrm{WO}=$ without antagonist, $\mathrm{WA}=$ with antagonist. $\mathrm{EE}=$ ethinyl estradiol. 


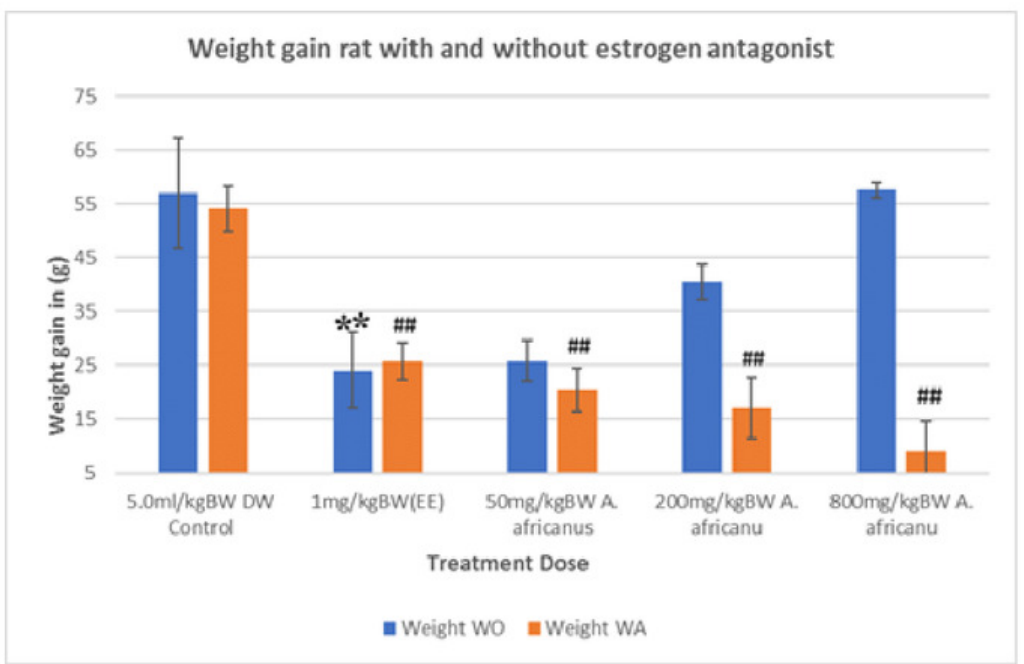


Figure 2

Oestrogen levels in rats treated with and without the administration of oestrogen receptor antagonist.

Values are expressed as mean \pm SEM, $n=6,{ }^{*} P<0.05$, and ${ }^{*} P<0.005$ vs. control without antagonist, ${ }^{\# \#} P<0.005$ vs. control with antagonist. $W O=$ without antagonist, $W A=$ with antagonist, $\mathrm{EE}=$ ethinyl estradiol. 


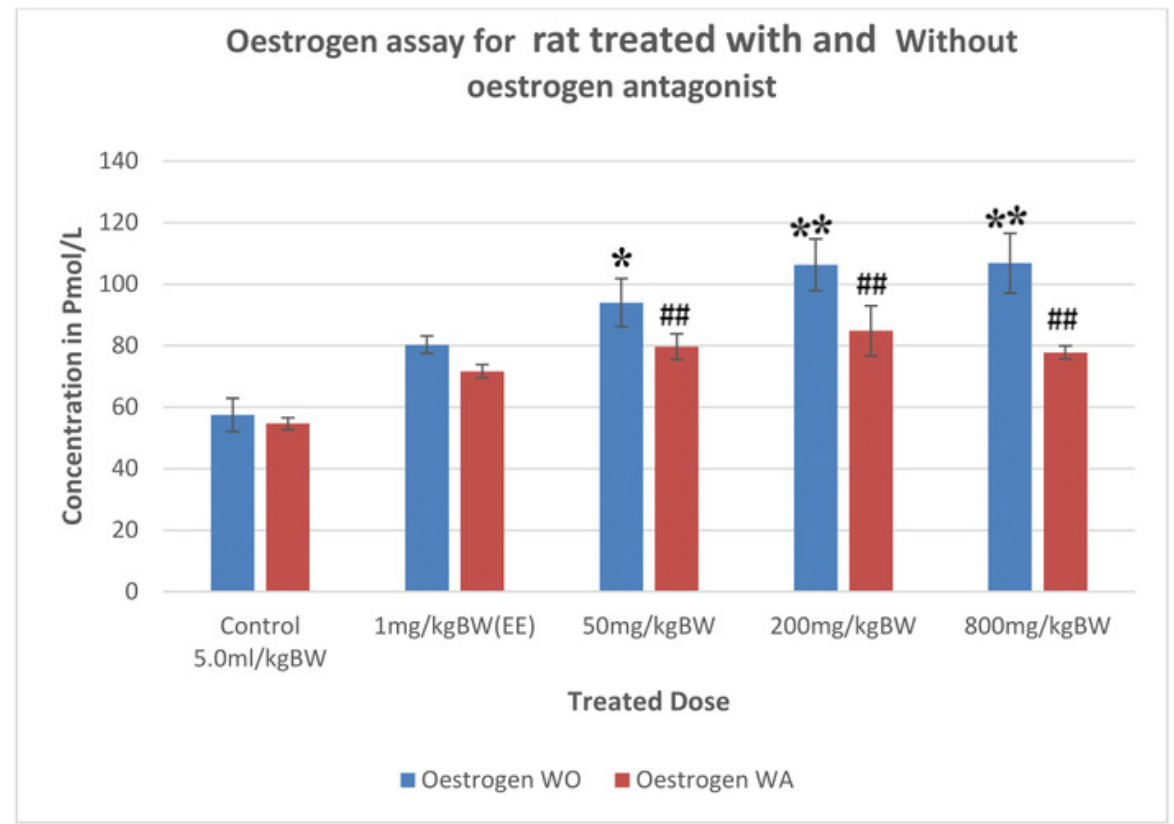


Figure 3

Progesterone levels in rats treated with and without oestrogen receptor antagonist.

Values are expressed as mean $\pm \mathrm{SEM},(n=6),{ }^{* *} \mathrm{P}<0.005$ vs. control without antagonist, ${ }^{\#} \mathrm{P}<$ 0.05 , and ${ }^{\# \#} P<0.005$ vs. control with antagonist. $W O=$ without antagonist, $W A=$ with antagonist, $\mathrm{EE}=$ ethinyl estradiol. 


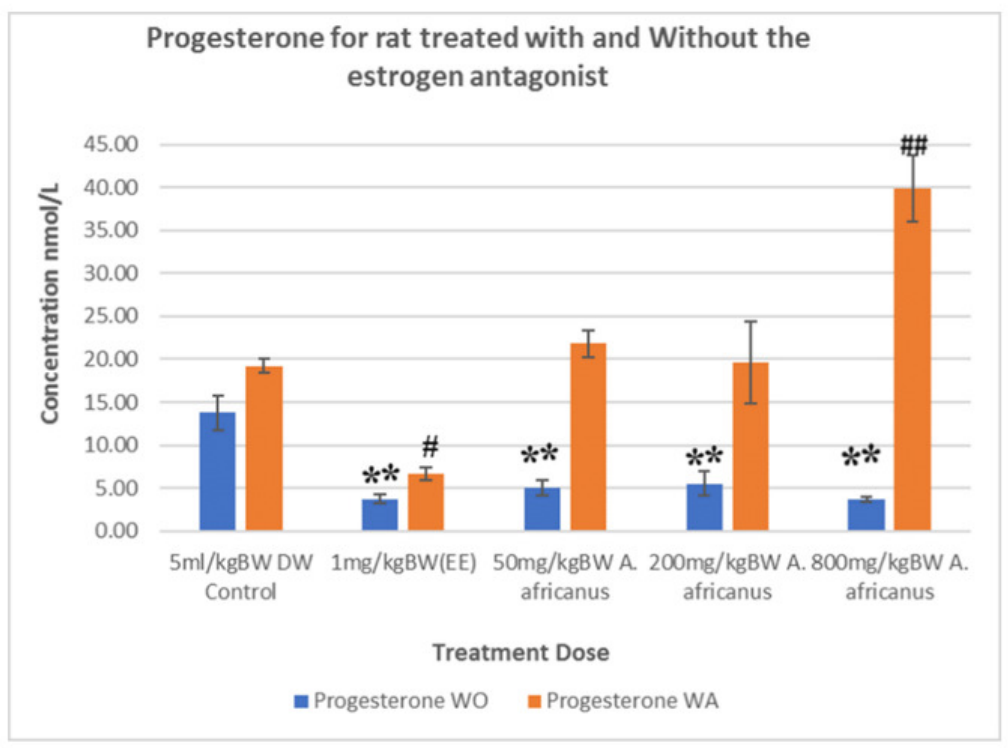


Figure 4

Luteinizing Hormone (LH) levels in rats treated with and without oestrogen receptor antagonist.

Values are expressed as mean $\pm \mathrm{SEM},(n=6) . \mathrm{WO}=$ without antagonist, WA $=$ with antagonist, $\mathrm{EE}=$ ethinyl estradiol. 


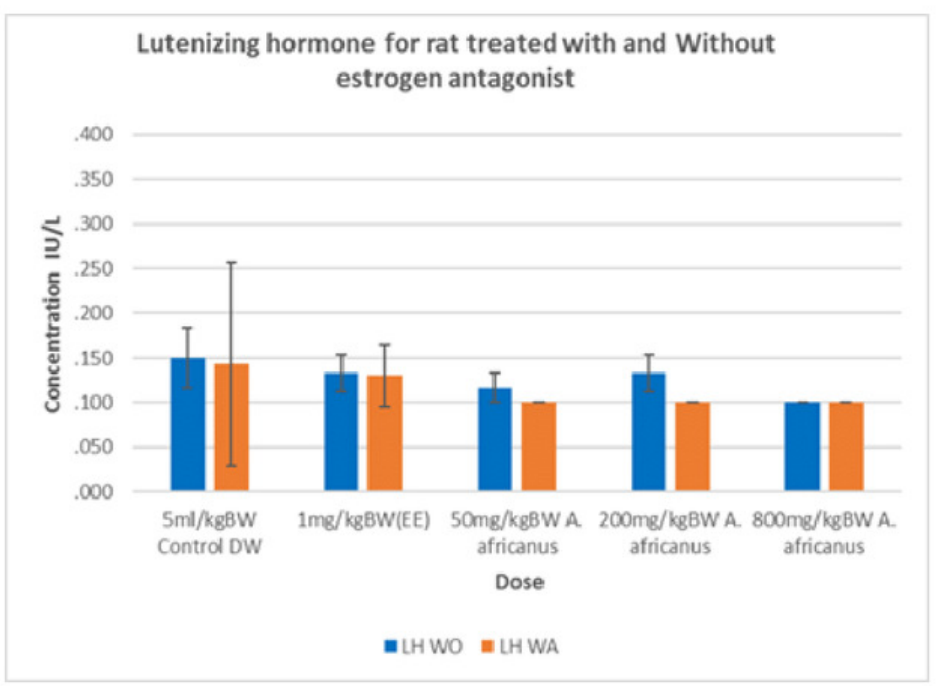




\section{Figure 5}

Graphical representation of gene expression of rats treated without oestrogen receptor antagonist.

Values were expressed and presented as mean \pm SEM, $(n=4), * p<0.005$ vs. calibrator without oestrogen receptor antagonist. $\mathrm{EE}=$ ethynyl estradiol, $\mathrm{E} r \alpha=$ oestrogen receptor alpha gene and Calb3= calbindin 3 gene . 


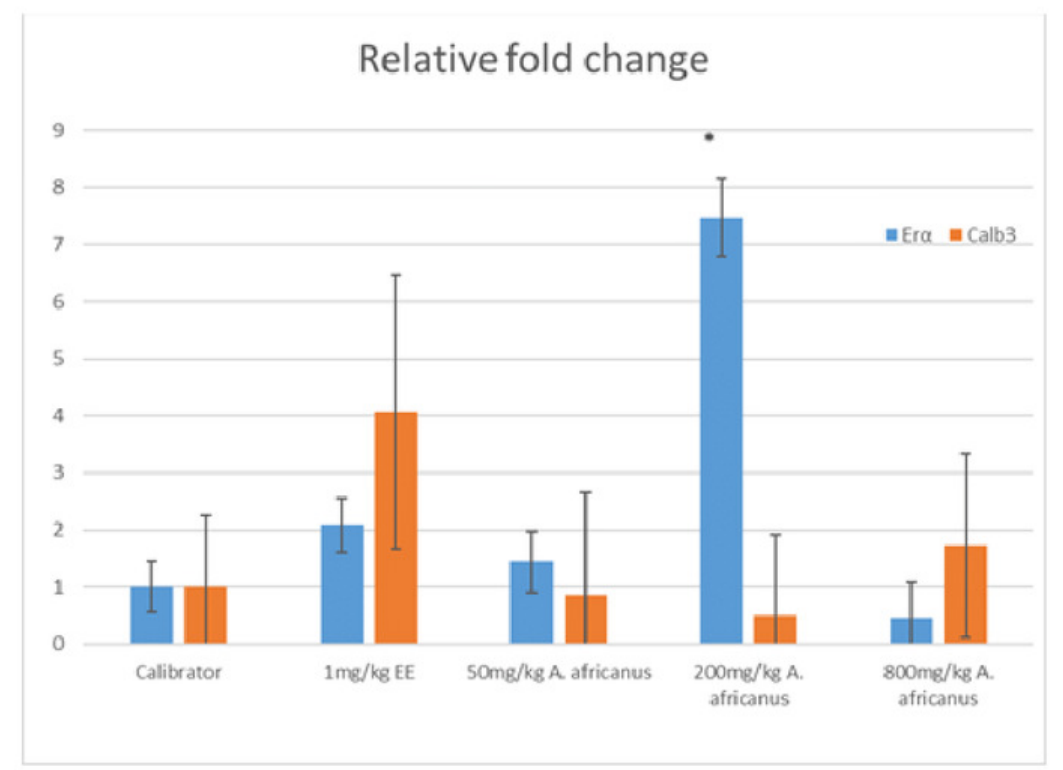


Figure 6

Graphical representation of gene expression of rats treated with oestrogen receptor antagonist.

Values were expressed and presented as mean $\pm S E M,(n=4), * p<0.005$ vs. calibrator with oestrogen receptor antagonist. $\mathrm{EE}=$ ethynyl estradiol, $\mathrm{Er} \alpha=$ oestrogen receptor alpha gene and Calb3= calbindin 3 gene. 


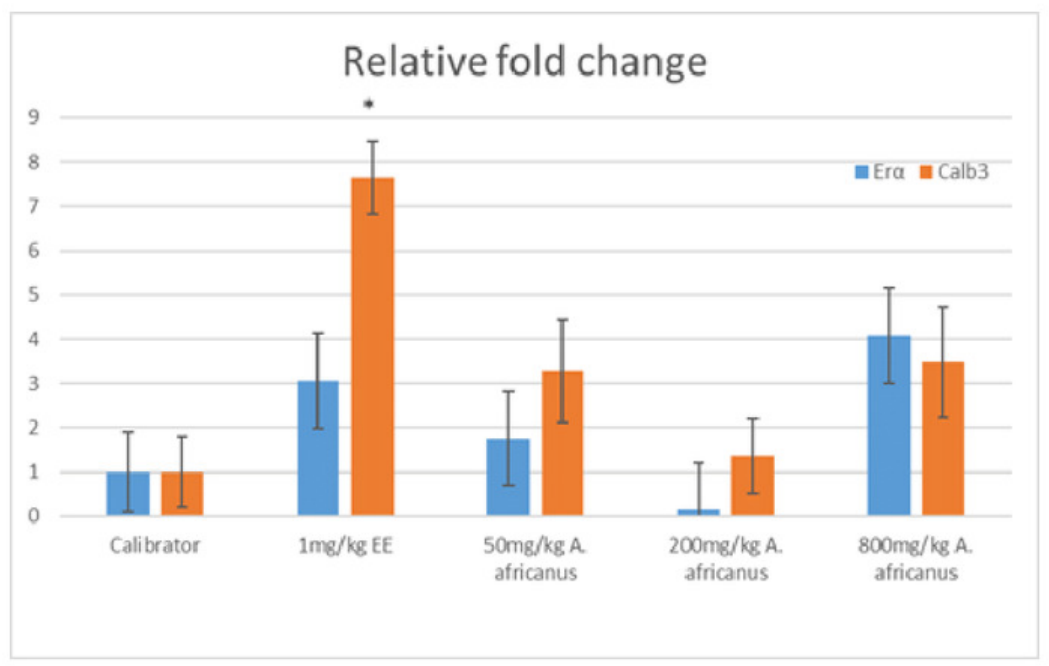


Figure 7

Chromatogram obtained from GC/MS analysis of aqueous root extract of Asparagus africanus 


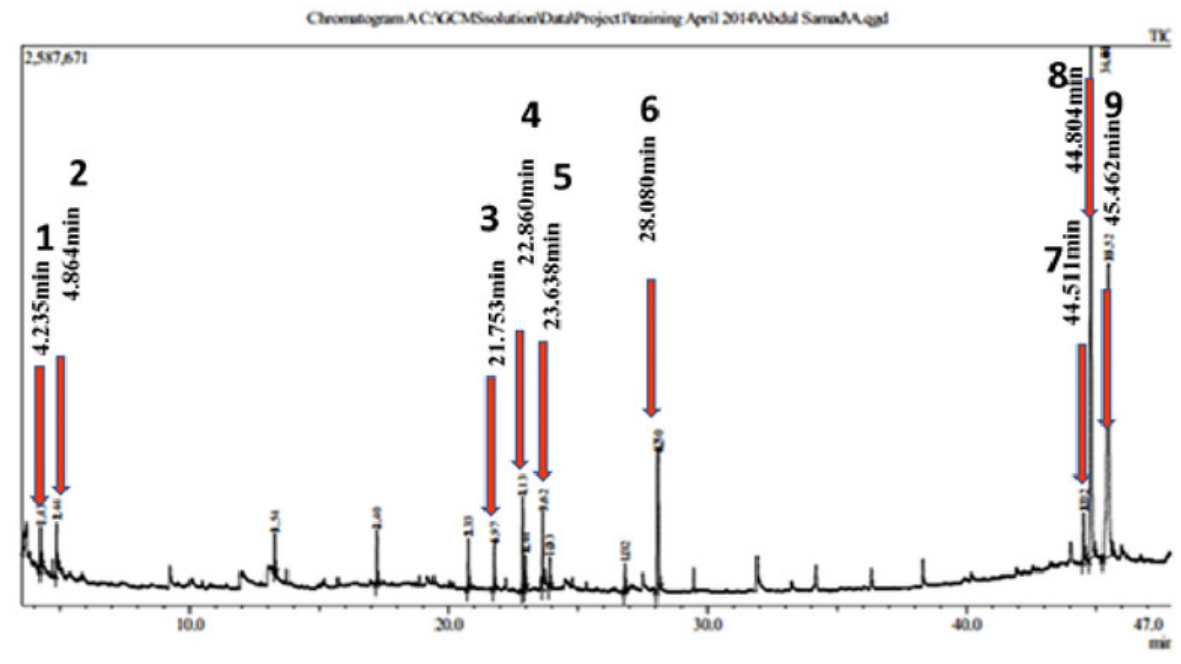




\section{Table $\mathbf{1}$ (on next page)}

Phytochemicals identified in aqueous root extract of Asparagus africanus using GC/MS

\# = Steroidal saponins in the aqueous root extract of Asparagus africanus 


\begin{tabular}{|c|c|c|c|c|c|c|c|c|}
\hline PeakNo & $\begin{array}{l}\text { RT } \\
(\min )\end{array}$ & $\begin{array}{r}\text { Area } \\
(\%)\end{array}$ & $\begin{array}{l}\text { Height } \\
\text { ( \%) }\end{array}$ & $\mathbf{m} / \mathbf{z}$ & $\begin{array}{r}\text { MW } \\
(\mathrm{g} / \mathrm{mol})\end{array}$ & CAS & $\begin{array}{l}\text { Chemical } \\
\text { Formula }\end{array}$ & Tentative Name \\
\hline 1 & 4.235 & 4.88 & 7.29 & 71.10 & 130 & $79-50-5$ & $\mathrm{C}_{6} \mathrm{H}_{10} \mathrm{O}_{3}$ & $\begin{array}{l}\text { 2(3H)-furanose,dihydro-3-hydroxy-4,4- } \\
\text { dimethyl }\end{array}$ \\
\hline 2 & 4.864 & 4.37 & 6.87 & 54.10 & 136 & $1124-11-4$ & $\mathrm{C}_{8} \mathrm{H}_{12} \mathrm{~N}_{2}$ & Tetramethylpyrazine \\
\hline 3 & 21.75 & 6.91 & 8.25 & 149.05 & 278 & $84-69-5$ & $\mathrm{C}_{16} \mathrm{H}_{22} \mathrm{O}_{4}$ & $\begin{array}{l}\text { 1,2-Benzenedicarboxylic acid, bis(2- } \\
\text { methylpropyl) }\end{array}$ \\
\hline 4 & 22.86 & 2.97 & 3.85 & 57.15 & 276 & $82304-66-3$ & $\mathrm{C}_{17} \mathrm{H}_{24} \mathrm{O}_{3}$ & $\begin{array}{l}\text { 7,9-Die-tert-butyl-1-oxospiro }(4,5) \text { deca- } \\
\text { 6,9-diene-2,8-dione }\end{array}$ \\
\hline 5 & 23.62 & 2.95 & 3.40 & 43.15 & 256 & $57-10-3$ & $\mathrm{C}_{16} \mathrm{H}_{32} \mathrm{O}_{2}$ & n-Hexadecanoic acid \\
\hline 6 & 28.08 & 12.09 & 16.01 & 185.10 & 360 & $77-94-1$ & $\mathrm{C}_{18} \mathrm{H}_{32} \mathrm{O}_{7}$ & Butyl citrate \\
\hline 7 & 44.51 & 1.82 & 1.68 & 55.15 & 412 & $77-94-1$ & $\mathrm{C}_{29} \mathrm{H}_{48} \mathrm{O}$ & Stigmasterol \# \\
\hline 8 & 44.80 & 40.78 & 34.07 & 139.10 & 416 & $126-19-2$ & $\mathrm{C}_{27} \mathrm{H}_{44} \mathrm{O}_{3}$ & Sarsasapogenin \# \\
\hline 9 & 45.46 & 23.18 & 18.55 & 139.10 & 414 & $0-00-0$ & $\mathrm{C}_{28} \mathrm{H}_{46} \mathrm{O}_{2}$ & $\begin{array}{l}\text { 3-Dehydro-des-N-26-methyl-dihydro- } \\
\text { nseudotomatidine }\end{array}$ \\
\hline
\end{tabular}

